Erik Knain

Universitetet i Oslo

Tobias Fredlund

Universitetet i Oslo

Anniken Furberg

Universitetet i Oslo

Ketil Mathiassen

Universitetet i Oslo

Kari Beate Remmen

Universitetet i Oslo

Marianne Ødegaard

Universitetet i Oslo

DOI: http://dx.doi.org/10.5617/adno.4722

\title{
Representing to learn in science education: Theoretical framework and analytical approaches
}

\begin{abstract}
Being able to engage with science representations, such as graphs, drawings, animations, gestures and written and verbal texts lies at the heart of scientific literacy. This article introduces the design-based research project Representations and Participation in School Science (REDE), which aims to investigate new aspects of how representations create learning and teaching opportunities in school science in lower and secondary school. It does so by scrutinising the role of representations in three areas of science education: the learning of science content, socio-scientific issues (SSI) and the nature of science. Central to the REDE project is the development of teaching designs whereby students' and teachers' engagement with various forms of representations are at the core of learning activities. The teaching designs are developed by teachers together with the researchers in REDE and are tested by the teachers and their students at three partner schools. In this article, we outline the theoretical framework of the project, which is based on scientific literacy and the notion of a 'third space'. We also introduce the design principles that inform the development of the teaching designs, as well as the two main analytical approaches that we use to analyse students' and teachers' engagement with science representations: multimodal analysis and interaction analysis. Finally, we illustrate the potential of the theoretical framework, the design principles and the multimodal analysis in contributing to the investigations in REDE. We do so by presenting and discussing analyses of
\end{abstract}


three empirical cases from classrooms where students worked with teaching designs that focus on representations.

Keywords: scientific literacy, representations, classroom research

\section{Læring i naturfag gjennom fokus på representasjoner: teoretisk rammeverk og analytiske tilnærminger}

\section{Sammendrag}

"Scientific literacy" og naturfaglig allmenndannelse innebcerer å mestre bruk av ulike representasjoner som grafer, tegninger, animasjoner og skrift. Artikkelen introduserer forsknings - og utviklingsprosjektet Representasjon og deltakelse i naturfag (REDE), som har som mål å undersøke og utvikle nye praksiser med fokus på bruk av representasjoner på ungdoms- og videregående trinn i norsk skole. REDE skal utvikle kunnskap og undervisningsressurser innen tre områder: begrepslcering, lering gjennom arbeid med sosiovitenskapelige spørsmål (SSI) og læring om naturvitenskapens egenart. Den design-baserte forskningen i REDE skal støtte utviklingen av aktiviteter som har fokus på representasjoner. Undervisningsoppleggene er utviklet $i$ samarbeid mellom forskere og lærere, og prøves ut på tre partnerskoler. I denne artikkelen beskrives det teoretiske rammeverket i prosjektet, hvor begrepene scientific literacy og det "tredje rom" står sentralt. Videre introduseres designprinsippene som ligger til grunn for utviklingen av undervisningsoppleggene, etterfulgt av en beskrivelse av to sentrale analytiske tilncerminger i REDE: multimodal analyse og interaksjonsanalyse. Avslutningsvis illustreres mulighetene som ligger i rammeverket ved hjelp av empiriske eksempler hentet fra tre klasseromssituasjoner der ulike undervisningsdesign ble implementert av larere og elever.

Nøkkelord: naturfaglig literacy, representasjoner, klasseromsforskning.

\section{Introduction}

An important characteristic of school science is its dependence on a number of representational forms, such as diagrams, graphs and equations, which have been developed by scientists over a long period of time (Knain \& Flyum, 2003). These forms of representations can also be encountered outside school, such as in news articles and in popular science. Learning to produce and interpret science representations is therefore an essential aspect of science learning (Lemke, 1998; Norris \& Phillips, 2003; Roberts, 2007; Tytler, Prain, Hubber, \& Waldrip, 2013). Much research has been conducted on student engagement with representations in naturalistic classroom settings. The results of this prior 
research have been drawn on, for example, to develop design principles for teaching (see Tytler et al., 2013). However, the existing research has mainly focused on the learning of science content, and there is almost no research on the role that representations play in students' use of scientific knowledge to participate in society, such as in making decisions regarding socio-scientific issues (see, for example, Tippett, 2016).

In this article, we introduce the REDE (Representation and Participation in School Science) project, whose aim is to investigate how representations create learning and teaching opportunities in school science, and to disseminate the resulting new knowledge to teachers and teacher education. The representational practices that REDE focuses on belong to three distinct yet related areas: the learning of science content, socio-scientific issues (SSI) and the nature of science. The aim of the present article is to outline and illustrate how our theoretical framework, the design principles for teaching that we use and our analytical frameworks, can help us investigate new aspects of the role of representations in the teaching and learning of science. To do so, we first introduce the project's theoretical framing, including the ideas of scientific literacy and third space. Next, we introduce the design principles for teaching, including amended versions of those developed by Tytler et al. (2013) for the learning of science content, and those developed by Sadler (2011) for SSI. We also present the analytical procedures that we use, namely multimodal analysis and interaction analysis. Finally, we present analyses of three extracts from empirical cases that illustrate how we intend to meet the aims of the research project.

\section{Theoretical framing}

\section{Scientific literacy}

The REDE project is based on the idea of scientific literacy. We use the term scientific literacy in a functional sense, meaning that scientific literacy enables participation in science discourses (Knain, 2015; Sørvik \& Mork, 2015). Roberts (2007, 2011) outlines what he calls different 'visions' of the purposes for learning school science: Vision I and Vision II. The purposes associated with Vision I have in common that they focus inwardly on the products and processes of science and entail participation in specialised science discourses. The purposes associated with Vision II focus on preparing students for handling outof-school issues such as citizens facing a variety of contexts and tasks. Thus, Vision II embraces participation in a broader sense of citizenship: as voters, parents, consumers, individuals and communities that enjoy, use and confront science when it impinges on their daily lives. Curricula therefore encompass aspects of both Vision I and II in different proportions (Roberts, 2007). REDE 
aims to analyse and develop representational practices as they relate to both Vision I and Vision II forms of scientific literacy.

Any sharing of science ideas depends on the production and interpretation of different representational forms, many of which have been constructed for specific scientific purposes (Knain \& Flyum, 2003). Science learning involves coming to appreciate how these different representational formats function and work together - in other words, to develop 'scientific literacy in the fundamental sense' (Norris \& Phillips, 2003, p. 230). Much research has been devoted to describing the importance of learning to use different representations appropriately, and to address student difficulties with particular representational forms. For example, Lemke (1990) described the importance of sharing knowledge through spoken language (1990). Since then, the argument has been extended to involve the importance of learning to use a multitude of representational forms (Ainsworth, 1999; Kress, Ogborn, Martins, \& McGillicuddy, 1996; Lemke, 1998; Roth \& McGinn, 1998).

The development of scientific literacy, in the fundamental sense, helps students to productively utilise representations in classroom interaction. This involves, for example, focusing students' attention and verbalising their understandings (Furberg, Kluge, \& Ludvigsen, 2013). Representations also support the development of modelling practices (Tasquier, Levrini, \& Dillon, 2016). Persistent visual representations, such as drawings or diagrams, can function as centres around which scientific meaning is negotiated in relation to using other representations such as gestures or spoken language (Fredlund, Airey, \& Linder, 2012; Kress et al., 1996).

\section{Third space}

Students are likely to engage with different types of discourses in school. Some types are more familiar, such as everyday discourses, and some are less familiar, such as more specialised discourses, including science (see Knain, 2015). Wallace (2004) emphasises that the school science curriculum should be located somewhere between these endpoints (Wallace, 2004, p. 903). In Wallace's (2004) view, successful learning has taken place when the student uses the language of science in a personally meaningful way. Teachers can support this by enabling students to take ownership of their ideas in what Wallace calls a 'third space'. The third space refers to a space for interpretation and negotiation of discourse and meaning that is neither dominated by the students' interpretations nor by those of the teacher. It is thus a space for explorative hybrid discourses where students' everyday language and ideas are blended with scientific language in a way that the students find meaningful. In this way, the students learn to participate in school science discourse, and they get to participate in shaping it. This is significant since there is seldom a balance between everyday and scientific discourses in the science classroom, and students often either try to conform to norms and expectations regarding what it 
means to 'be scientific' or to refrain from engaging with science at all. While Wallace's (2004) description of the third space focuses exclusively on verbal language, the way that the third space is used in the REDE project also includes other representational forms that characterise school science - diagrams, graphs, equations, etc. (Knain, 2006; Kress et al., 1996). In the REDE project, successful learning is therefore seen as having taken place when students produce and interpret the different representations that they encounter in science education in a personally meaningful way. The project also makes the assumption that the teaching and learning that take as their starting point the students' own representations can help in establishing a third space for students in their learning process. This is reflected in the design principles for teaching (see the next section).

To create good opportunities for students to learn to participate confidently in science discourse, the REDE project also strives to establish a third space in the classroom that encompasses both the students' own experiences and discourses, and the ideas and input from the resources and authoritative voices of science discourse. The teacher has an important role in facilitating the dynamic between these discourses in the third space (Scott, Mortimer, \& Aguiar, 2006).

\section{Designing teaching that focuses on representations}

\section{Designing teaching for the learning of science content}

To design teaching for the learning of science content, the REDE project applies design principles. Bell, Hoadley and Linn (2004) describe design principles as:

....an intermediate step between scientific findings, which must be generalized and replicable, and local experiences or examples that come up in practice. Because of the need to interpret design-principles, they are not as readily falsifiable as scientific laws. The principles are generated inductively from prior examples of success and are subject to refinement over time as others try to adapt them to their own experiences. (p. 83)

Drawing on design principles is central to design-based research (DBR). The DBR methodology applied in REDE emphasises meaning-making in authentic settings, the involvement of teachers in the teaching design, and flexible design revision (Barab \& Squire, 2004; Krange \& Ludvigsen, 2009).

In the REDE project, the design of teaching for the learning of science content is informed by the design principles in Tytler et al. (2013). These are presented below in a slightly amended form. The resulting teaching designs are then used in the teaching and learning taking place in our partner schools.

Design principles for the teaching of science content: 
1. When planning the teaching, the teacher should determine the central disciplinary concepts and theories to be taught. This is the starting point for identifying the central representations that the students should work with to learn about the science content. The representations should be used in formative and summative assessment.

2. The teacher should craft a trajectory of tasks and activities for students, in which they get to express and explore their own ideas, extend them to new situations and integrate them. Students should be able to experience activity sequences as meaningful and interesting.

3. The teacher should focus explicitly on the form and function of different representations and explicate how different elements in the representation stand in relation to experience, phenomena and concepts. The assumption here is that students will be encouraged to see the connections between a representation and what it represents.

4. The students need practice in producing their own representations in order to enhance and demonstrate their understanding.

5. Students should be encouraged and supported in using different representations and in trying to see the connections between them. They should come to appreciate that different forms of representation have different possibilities and that several representations will be needed to explain a phenomenon.

6. The students need opportunities to discuss their own representations in relation to the teacher's representations (and/or those of other authoritative sources). They should have the opportunity to practice to judge the quality and relevance of their own representations.

7. Teachers should point to similarities between how researchers use representations and how students use them.

Tytler et al. (2013) characterise the form of teaching that uses these principles as guided inquiry, which we would describe as a teaching design that fosters productive engagement with representations of science to support inquiry into scientific phenomena and theories. In the REDE project, we see guided inquiry as aligning with the idea of a third space where the teacher supports student engagement and learning. As the project proceeds, we anticipate that the design principles will be challenged and developed iteratively.

\section{Designing teaching to address socio-scientific issues}

Scientific literacy does not simply mean being able to read and write scientific texts. There is also a broader societal side to it, which involves students becoming prepared to participate in a rapidly changing world (Roberts, 2007). Such participation includes, for example, decision making in out-of-school contexts. In order to prepare students for such participation, science education must help them to become users of knowledge for specific social purposes 
(Jenkins, 1994). This includes participation in democratic processes and taking personal action on complex societal issues. When conflicts of interest, risk and uncertainty emerge, scientific knowledge no longer takes a self-evident role; it becomes vested in ethical and political concerns (Kolstø, 2001). Teaching students to participate in SSI is therefore difficult. SSI involves controversial topics that encompass both society and science. Characteristic of SSI is also that decisions are not necessarily simply right or wrong. SSI can be encountered in daily situations, such as when we read the news or when we participate in interest groups. Examples include fish farming, gene testing, how to preserve endangered species and conflicts of interest that concern the Norwegian offshore fossil fuel industry. In the REDE project, SSI-based teaching and learning are seen as being supported by teaching designs that provide possibilities to open a third space. This is because such designs would allow multiple discourses to be brought together, each characterised by different forms of representations, genres and content. Thus, representations can help students manage the complexity of SSI by providing structure and focusing their arguments.

Using Sadler's (2011) framework for SSI-based science education, the actual teaching designs for addressing the SSI used in the REDE project were developed by the researchers together with the teachers at the partner schools. Sadler's idea of building teaching around a compelling issue that is presented at the outset is particularly important in the project. Sadler (2011) presents a number of design principles for SSI, which include the use of science-related topics that appear in the media as a way to connect school science with the real world (Klosterman, Sadler, \& Brown, 2012). Furthermore, science-related media reports can simulate participation outside school and support the hybrid discourse in the third space in SSI settings. The teacher and the textbook can present further scientific aspects. However, Sadler's (2011) framework for SSIbased science education does not include a particular focus on representations. Therefore, we have modified his design elements to align with the purposes of REDE. The resulting design principles are presented below.

1. Build the teaching around a compelling issue that engages students.

2. Introduce the topic first. Find representations that are central to the topic. Decide when and to what extent students should have control of delimiting the topic and finding representations.

3. Let students collect and/or analyse evidence/data related to the topic and focus on the use of appropriate forms of representations.

4. Craft explorative/inquiring forms of education whereby students get to express/communicate and explore their own ideas.

5. Provide support for higher order praxes: argumentation, evaluation, critique and decision-making, by focusing explicitly on the form and function of different representations and by comparing and contrasting 
them. Concretise how different representations are part of, and interpreted by, different parties in a conflict of interest or a dilemma. Students need practice in assessing the quality and relevance of their own representations and those of others.

6. Use media to connect the classroom with the outside world.

7. Bring out the scientific questions that are relevant to the topic, and let the students approach them through representations, separately and/or several together.

8. Bring out the social and ethical aspects of the topic as well as representations that point to these aspects. Focus the teaching on conflicts of interest and dilemmas.

9. Bring up aspects of nature of science in relation to the topic. Representations can function as starting points for discussions about ethical aspects and what counts as evidence. Teachers can also say something about how researchers have developed the representations.

\section{Analytical approaches}

The REDE project draws on different complementary research traditions to analyse teaching and learning with representations in lower and upper secondary education. The first analytical approach is multimodality, which focuses on meaning-making in the form of production and interpretation of multimodal text. The other analytical approach is interaction analysis, which focuses more on how representations are used in the interaction between students working in groups and/or between students and the teacher. Although we mostly use multimodality in this paper, we will give an outline of both analytical approaches.

For our multimodal analyses of representations, we draw on the construct mode, which is a 'socially shaped and culturally given resource for meaningmaking' (Kress, 2013, p. 60). 'Image, writing, layout, music, speech, moving image, soundtrack are examples of modes...' (Kress, 2013, p. 60). Scientific representations are often constituted by clusters' of modes (see Baldry \& Thibault, 2006; Knain, 2015). For example, a graph figure might include drawn lines and written language as well as equations. Student meaning-making involves making connections within and across the constituent modes of a representation, for instance, by pointing (gesture) to a line (drawing) while making statements (talk) (cf. Tang, Delgado, \& Birr Moje, 2014).

The ways in which students produce text depend on their interests and their interpretation of the situation (Bezemer \& Kress, 2015; Kress, Jewitt, Ogborn, \& Tsatsarelis, 2001; Kress \& Selander, 2012). In the REDE project, we view the discourse taking place in the third space as an indication of the learning that can, and does, take place; and we view students' representations as evidence of 
learning (Kress \& Selander, 2012). From this point of view, students who participate in lively and personally meaningful discussions and inquire into science topics can have unique possibilities for learning.

The analysis of multimodal text can also render insights into how designed learning environments can influence engagement. Such environments are provided by, for example, textbooks, the teacher and the students in their ongoing interaction. Bezemer and Kress (2015) provide the following list of analytical aspects that guide the designs of learning environments: framing (delimiting a space that enables some aspects of the content to be focused on and others to recede to the background), selection (what is to be included in the frame and how), arrangement (what kinds of representations and signs are important and in what order) and foregrounding (what is made salient as particularly important - and how). In addition, what a particular representation means in a given situation depends on the affordances and constraints of that representation (Fredlund et al., 2012; Kress, 2010; Tytler et al., 2013). The term affordance concerns the possibilities for meaning-making that a representation or mode provides. Framing, selection, arrangement, foregrounding and affordance are thus five important analytical aspects that affect student meaningmaking in the third space.

A second analytical approach within the REDE project is interaction analysis (Jordan \& Henderson, 1995). Interaction analysis (hereafter IA) can be seen as an interdisciplinary method with roots in research fields such as ethnography, sociolinguistics, ethnomethodology, conversation analysis and sociocultural theories. There are two significant aspects of IA. First, its analytical focus is on talk-in-interaction and participants' engagement with objects and artefacts, such as representations. Second, IA combines micro-level analysis and the use of ethnographic data to provide the 'thick descriptions' of an observed activity, which are necessary for understanding social interactions (Geertz, 1973).

The analytical procedure of an IA approach involves a sequential analysis of the talk and interaction between participants in classroom settings (Furberg et al., 2013; Jordan \& Henderson, 1995). A sequential analysis implies that each utterance in an on-going interaction is considered in relation to the previous utterance(s). As a result, the focus is not on the meaning of single utterances, but on how meaning is created within the exchange of utterances (Mercer, 2004). Another feature of IA, as it is applied in this project, is that the analyses often involve an analytical focus on interaction trajectories, which refers to analyses of interactions taking place over time, such as within one or more lessons or in a larger science project (Ludvigsen, Rasmussen, Krange, Moen, \& Middleton, 2011; Strømme \& Furberg, 2015). By exploring students' and teachers' interaction trajectories, we can investigate both how changes take place over time in student meaning-making, as the students produce and interpret representations, and how different kinds of support influence meaning-making processes. 
Teaching designs focusing on interaction with representations: Cases from science classrooms

\section{Research design and data material}

In this section, we present empirical cases from three different settings (Cases 1-3) where teaching designs have been tried out by teachers and students at one of our partner schools. The teaching designs were developed by the teachers in collaboration with the researchers on the REDE project. The aforementioned design principles guided the development of the teaching designs, which were aimed at supporting the students' understanding of science content and SSI. Throughout this section, we refer to the different design principles presented above.

The participating students (ages 15-16) were in their first year of upper secondary education, and were taking their last compulsory science course. Video data from classroom interaction and interviews with students and teachers were collected. Drawings and other texts that the students produced were also collected or saved electronically.

In what follows, we present multimodal analyses of three excerpts from the empirical cases. A common theme in the teaching designs in these cases is climate change, which is a central theme in the Norwegian national science curriculum for both lower and upper secondary school (see Utdanningsdirektoratet, n.d.). This theme is therefore appropriate for studying the teaching and learning of science content and has often been shown to be challenging for students (Hansen, 2010; Niebert \& Gropengießer, 2013; Tasquier et al., 2016). The theme also gives a rich context for studying SSI, as SSI deals with controversial topics relating to science content.

The cases also illustrate and anchor the discussion of some of the theoretical and analytical notions introduced earlier: the third space, framing, foregrounding and affordance. The first two empirical cases deal with the teaching and learning of science content. The difference between these two cases is that in the first, the teacher engages with a group of students, whereas in the other, no teacher is present while a group of students are working. The third case is from an SSI setting where a group of students are working together to produce an argumentative text.

\section{The learning of science content: Explaining the greenhouse effect Case 1: Representations and student-teacher interactions}

In the first empirical case, the students were presented with an experiment illustrating the greenhouse effect (see Figure 1). The students' task was to work in groups of two to create a drawing that explains what was happening in the experiment (see design principles 1 and 4 for the learning of science content). The experimental setup consisted of two beakers, one of which was filled with ordinary air and the other with a larger percentage of carbon dioxide. A strong 
working lamp was shining onto both beakers, and thermometers were used to indicate the temperature inside them. The students were allowed to use their textbooks and computers as resources (see design principles 5 and 6 for the learning of science content). When the students had completed their drawings, the teacher told them to form new groups consisting of two previous groups. Each new group of four students was then supposed to sketch a new drawing based on those that each of the two constituent student groups had previously drawn.

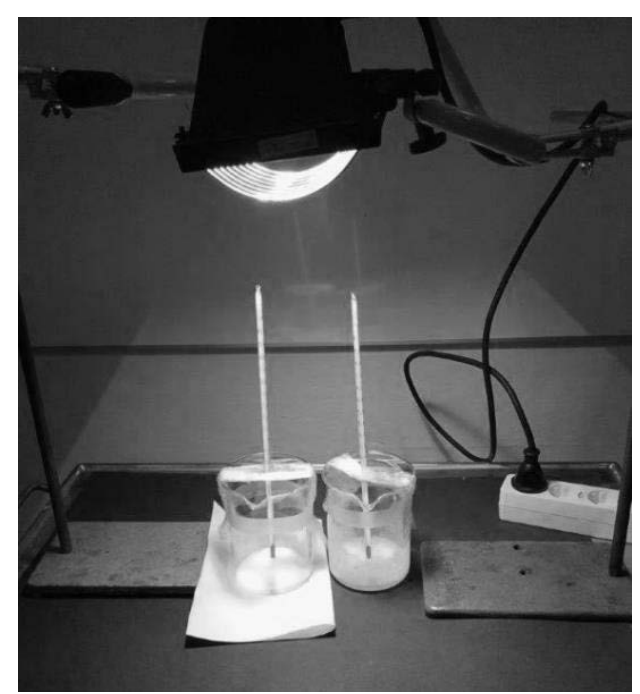

Figure 1. The experimental setup

In Excerpt 1, the four students Paul, Ali, Finn and Hans (pseudonyms) are struggling to develop their drawing further. They have asked the teacher to guide them as to how to proceed in order to explain what was taking place in the beakers. At this point, they have already drawn a lamp, two beakers labelled with their gaseous content and radiation that propagates from the lamp into and out of the beakers (shown with arrows in Figure 2). The following dialogue then took place: 


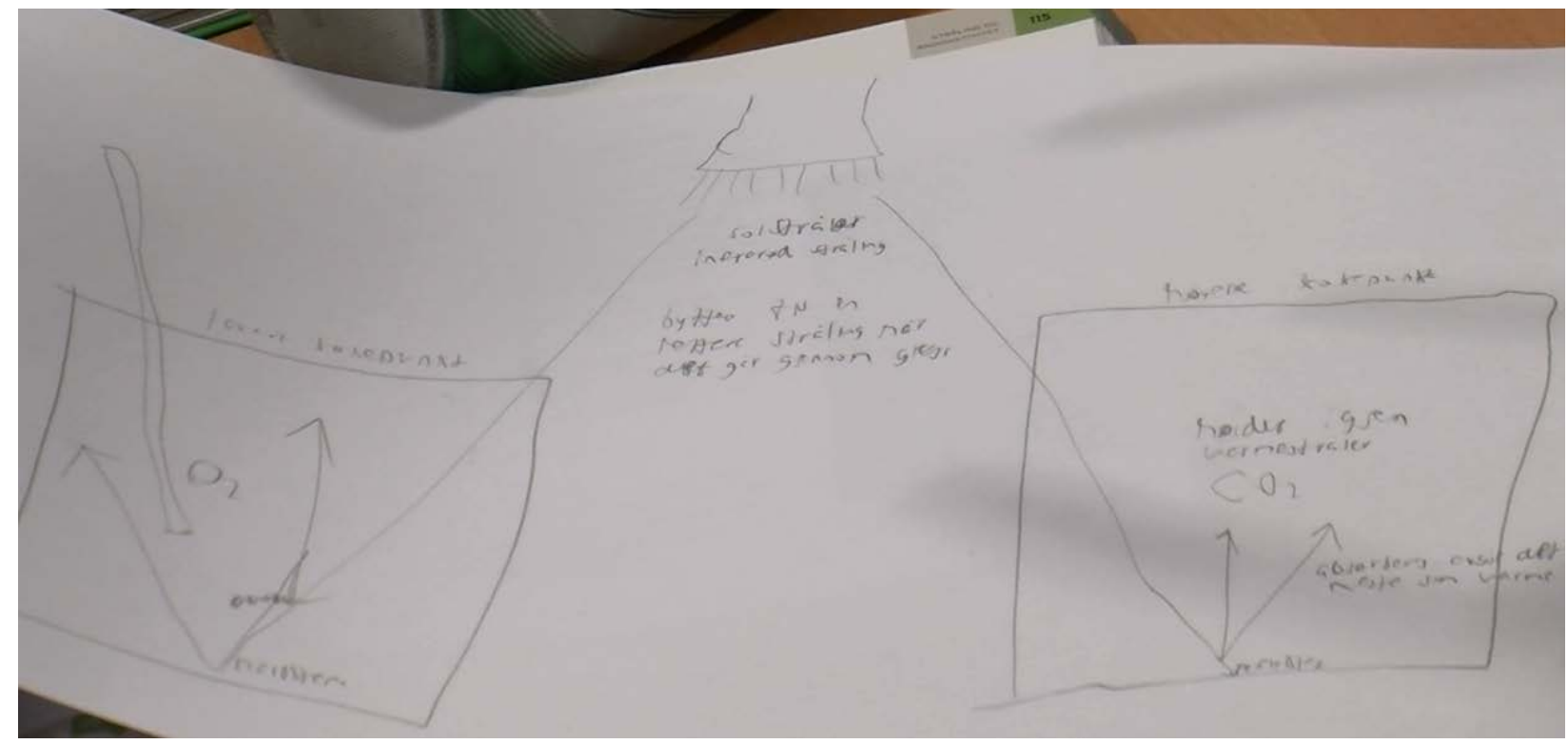

Figure 2: Group drawing 1 (before teacher dialogue).

\section{Excerpt 1:}

1. Teacher: Well, there are different types of radiation that can pass through different types of materials. Not all types pass through all material types. So what happens is that both visible light and heat radiation [points at the group's drawing] passes through oxygen and nitrogen. It is transparent to them.

2. Paul: Yes.

3. Teacher: But visible..., when it comes to $\mathrm{CO}_{2}$, steam and methane - the most important greenhouse gases...

4. Ali: It is visible light...

5. Teacher: They are transparent to visible light.

6. Paul: Yes.

7. Ali: But not to heat radiation.

8. Teacher: They are not entirely transparent to heat radiation, which will be partly absorbed and then sent back again towards the earth.

9. Paul: Uhum. We have written that.

10. Ali: Oh yes, so here [points at the drawing of the beaker with ordinary air] both pass through, both visible and heat [radiation]. While here [points at the drawing of the beaker with $\mathrm{CO}_{2}$ ], only visible passes, but not heat?

11. Teacher: Some of the heat, but not all of it.

12. Ali: Not all. Right?

13. Teacher: Yes.

14. Ali: $\quad$ So some of it is absorbed?

15. Teacher: Uhum. So how do we separate the short-waved radiation from the sun and the long-waved radiation that is sent up from the ground? Is there any way to show that in the drawing - that they are different?

16. Andy: Those longer waves

17. Finn: Longer waves

18. Ali: That we make one longer than the other or...? [points at the drawing as well as at the length of the arrow pointing downward and the one pointing upward]

19. Paul: Yes, one longer than the other, or? [points at the arrows in the $\mathrm{CO}_{2}$ beaker]

20. Teacher: [Points at the same arrows)) Yes, but this only suggests that it has travelled longer.

21. Paul: Yes, the waves are wave tops and so on, but should we make (.) [points into the air and makes a brief wave-like gesture] along the way? 
22. Teacher: Yes, is there any way to show...? How has the book shown waves?

23. Ali: [turning the pages of the textbook]. Uhm. ((points at how light has been drawn as wave-shaped arrows with different wavelengths in a textbook image]. Oh yes, so that...

24. Teacher: Can one see that there is any difference between the different types of radiation?

25. Paul: [points at the arrows in the book that indicate heat radiation]Yes, the length of the waves is longer.

26. Ali: And the others are shorter.

27. Teacher: Yes.

In this excerpt, the drawing provided a frame for the teacher-student discourse. The teacher pointed to the drawing as he talked (Turn 2), and so did Ali (Turn 11). The students' gestures connected the drawing with their oral accounts. The affordance of talk, where meaning unfolds in time, was thus balanced by the affordance of the diagram, which shows how things are located spatially in a more time-independent manner. At the same time, the oral language and gestures were foregrounded with the drawing as their background.

At Turn 16, the teacher changed the focus of the discourse to one on how different types of radiation could be represented. Here, the distinction between short- and long-wave radiation was foregrounded, and the dialogue turned towards how this distinction could be made visible in the drawing - in other words, which representation would have the appropriate affordance to provide access to this aspect of science knowledge. The teacher then used the textbook as a resource in the negotiation of meaning about this topic (Turns 23-28). The three modes of talk, gesture and drawing were all involved in the shifts in the foregrounding and backgrounding of meaning that led to the students becoming aware of relevant aspects of the science content and appropriate ways of representing them. In terms of design principles, the teacher addressed the form and function of the representations (design principle 3 for the learning of science content), and called upon authoritative resources when judging the appropriateness of representing radiation (design principle 6 for the learning of science content).

This empirical case also shows that by producing the drawing, the students had been given the freedom to open up a third space for shared meaningmaking, to which the teacher made occasional contributions. Even though the teacher took the primary responsibility for developing the scientific account, it was grounded in the students' drawing. Thanks to this, the discussions were not conditional only on the teacher's contributions, as warned for by Mestad and Kolstø (2014).

\section{Case 2: Representations and student-student interactions}

Our second empirical case is taken from a classroom setting where the students were working with a different experimental setup than that in Case 1, but the task was the same. 


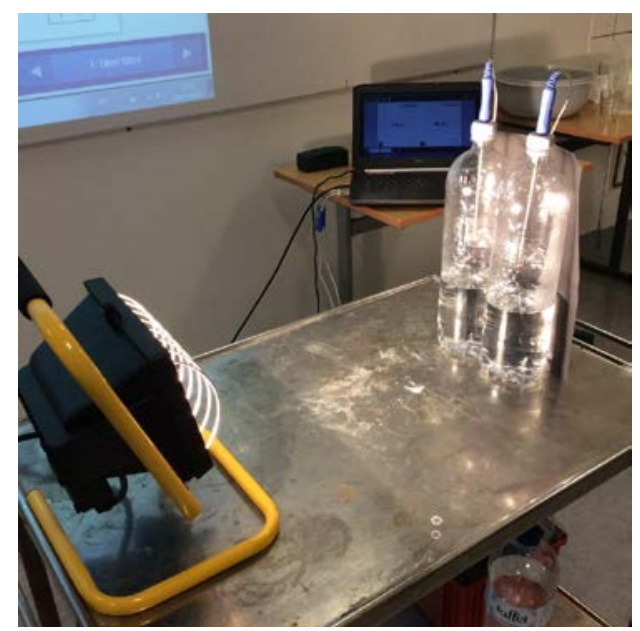

Figure 3. The experimental setup in Case 2

In this case, the containers used were not open beakers, but plastic bottles. One bottle contained ordinary air and the other a larger percentage of carbon dioxide. The same working lamp as in Case 1 was used, and a black sheet of paper was positioned behind the bottles, functioning as the earth's surface. In Excerpt 2, the four students Chris, Lea, Siri and William (pseudonyms) are sketching a joint drawing, with Chris as the main author. They struggle with how to explain the roles that the absorption and reflection of radiation play in the greenhouse effect and how to demonstrate it in their drawing. In the drawing, they have already drawn an energy source, radiation from the energy source, two bottles with different gaseous content and a black sheet behind the bottles (see Figure 4).

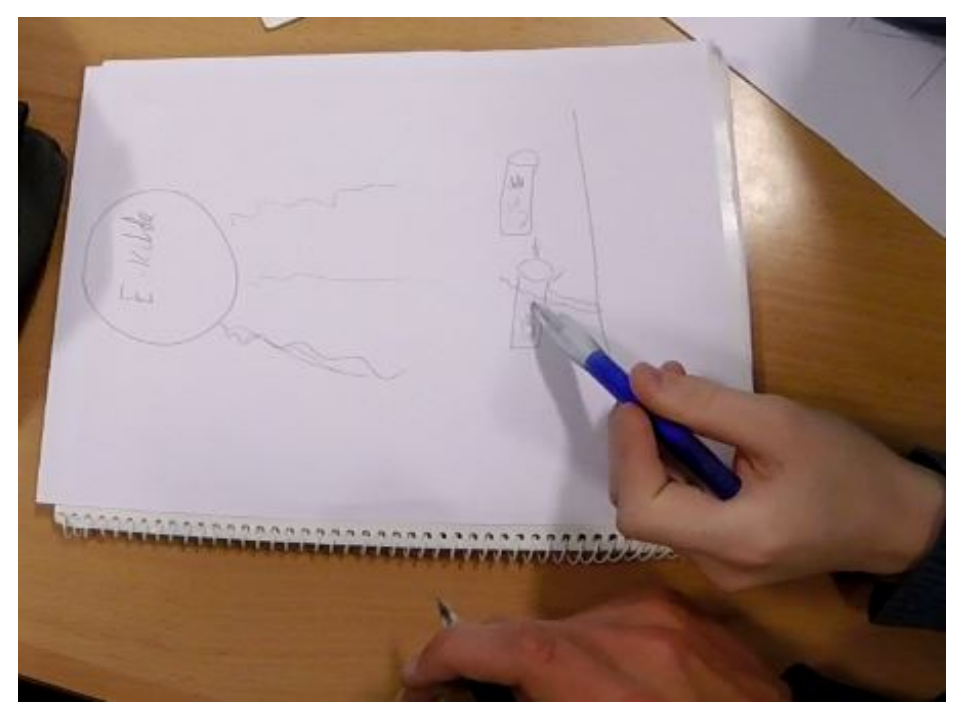

Figure 4. The students working on their joint drawing of the greenhouse effect 
Excerpt 2:

1. Chris: [Draws a wiggly line to the right, through the bottle containing more $\mathrm{CO}_{2}$, to the black sheet and back to the left to the bottle's surface [see Figure 4], from where wiggly lines are drawn in different directions]

2. Siri: But what you mean is that it is reflected through... to the sheet and back?

3. William Yes.

4. Chris: Yes.

5. Lea: I thought the sheet absorbed...

6. William Yes.

7. Siri: I suppose it absorbs some and reflects...

8. William I suppose it absorbs some. But, you know, when the water... or, when the light comes here ((tracing the light propagating rightward towards the bottle with his pen)), with the bottle, it heats the bottle, and then it goes into the sheet, the black sheet, and some is reflected back, and then... ((circles with his pen inside the sketched bottle with $\mathrm{CO}_{2}$ )) [see Figure 4].

9. Siri: $\quad \mathrm{CO}_{2}$ will take it up.

Excerpt 2 shows that the students were trying to make sense of the experimental setup and interpreted the experiment by using the affordances of talk, their drawing and gesturing with the pen. The drawing became something that the students shared and whose meaning they could negotiate, thus serving an important function by enabling the emerging explanation. At the same time, the constraints of the drawing, such as that the distinction between absorption and reflection could not be seen in it, also became obvious (Turn 7). Reflection and absorption were gradually foregrounded in their talk, but the differences between the physical processes were not made explicit.

The drawing, the gestures and the talk have complementary affordances. For example, the extract shows how well talk functions to address more uncertain aspects of the physical processes involved. The drawing functioned as a frame for the talk and gestures about what happens with the radiation in this setting, where the students engaged with meaning-making without the teacher being present. In a sense, the teacher's absence also made the discourse here more student-centred in comparison with Case 1. This led the meaning-making to progress more slowly, and the language that the students used to express was more tentative ('I thought...' (Turn 5), 'I suppose...' (Turn 7)).

With respect to the third space, the discussion was largely dominated by the students' own discourse. However, as the students used science terms such as 'absorbs' and 'reflects' and discussed what happens with the light from the energy source, the third space could still be seen to be opened up. Still, the full potential of working in a third space could not be met until the students consulted other authoritative sources, such as the textbook or the teacher. For example, the teacher could help them clarify the meaning of absorption and reflection and how these terms relate to the light, the $\mathrm{CO}_{2}$ and the rest of the experimental setup. 


\section{SSI: For or against further oil exploration}

\section{Case 3: Representations and student-student interaction in an SSI setting}

In a different lesson, the students from Case 2 were assigned the roles of representing either the Norwegian state or a non-governmental organisation (NGO) in a forthcoming lawsuit against the Norwegian state, issued by two NGOs. This implied that the students' roles were either for or against further Norwegian off-shore oil exploration. Two argumentative op-eds supporting different sides of the conflict were used as an introduction to the topic. This is an example of an SSI that is both authentic, ongoing and present in the media (see SSI design principles 1, 2 and 6). The students were provided with various preselected representations, including diagrams, graphs and images, that the teacher and researchers had found on the internet and in the students' science textbook (SSI design principle 3 - let the students analyse evidence relevant to the topic). The students' task was to select representations from those provided and to use them to produce a text that argued for their assigned standpoint in the conflict (SSI design principle 5). In Excerpt 3, the students Tim, Ben, and Emma (pseudonyms) are trying to find representations in support of their arguments.

Excerpt 3:

1. Tim: Ok, which one should we use? Should we use that one? [refers to the image in Figure 5, shown on the students' computer screen]

2. Ben: That's a good one to use

3. Tim: Yes, but what does it explain to me, then? Let me look at it ((gets it on paper from Ben)). It is hard to read there... [moves his finger in a small gesture towards the computer screen]

4. Emma We should start to write.

5. Tim: Yes, I know that, but we must just see... Ok, you can start to write an introduction if you want to, and a heading [passes the computer to Emma] while we just... I just need to look at this one [points at the representation on paper]

6. Emma You take the heading at the end.

7. Tim: Yes, fine, introduction then.

8. Ben: [Points in the diagram/representation] [Figure 5] This shows that Norway is a very important country in oil production. ....and gas.

9. Tim: How does that support us? How can this support us?

10. Ben: Because it is important that we, kind of, produce gas etcetera to the world. 


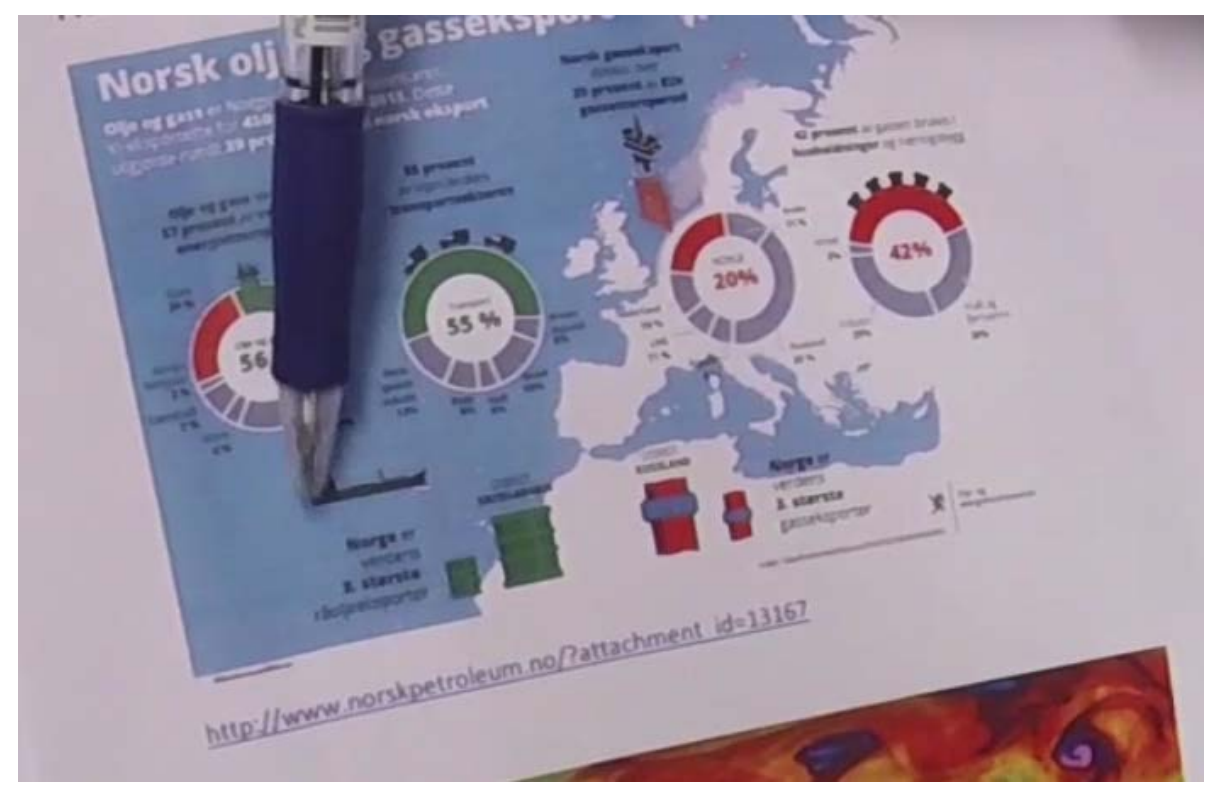

Figure 5. The diagram that the students selected for their SSI argumentation

In Excerpt 3, the students' focus of interest is different from those of the first two cases. The excerpt exemplifies the challenges that the students faced when trying to find and interpret representations to support their argument. The representation, which consists of a cluster of modes, was first judged as being useful by Ben (Turn 2), and then Tim subjected it to a more detailed interpretive investigation to find out what it means (Turn 3). Tim reported his interpretation of the representation and its affordances to the others in Turn 8. The students opened up two problem areas: what the representation means (Turns 5 and 8) and how it can support their assigned argument (Turn 9). Apart from this, the excerpt also shows that the students were aware of the need to produce a text (Turns 4-6). Although the representation did not afford much access to science content, it offered factual backing of the students' argument. Looking at this discussion in terms of opening up a third space shows that this space included not only the negotiation and expression of a scientific interpretation, it also included the use of the representation as an authoritative premise in the students' argumentation.

\section{Discussion and concluding remarks}

Our premise in this article has been that the ability to engage with representations - to produce and interpret them and use them for various purposes - is at the heart of scientific literacy. Scientific literacy, in turn, is a cornerstone of the REDE project. In this article, we have outlined the theoretical framework, the design principles and the analytical approaches that form the basis of the REDE project and how they make it possible to investigate new aspects of using representations in the teaching and learning of science. The 
three empirical cases illustrate some of the roles that representations play in the learning of both science content and socio-scientific issues.

In the REDE project, we draw on the idea of third space, which refers to those transformations of multimodal representations that mediate between student-centred and specialised discourses. The potential of focusing on representations to bridge student-centred and authoritative accounts is evident in Case 1. Even in the teacher-led authoritative account, the focus of attention was not on what long- and short-wave radiation 'is', but rather on how it should be represented in the students' drawings. Thus, a student-generated element remained central in the discourse at the same time that the teacher tried to foreground something that was relevant to the students' explanation. This was also an attempt to draw the students' attention to the affordances of the waveshape.

In contrast to Case 1, in Case 2, the third space did not meet its full potential. The absence of the teacher led to the meaning of the terms not being challenged as well as an increased provisionality of meaning. This is because when the teacher's or the students' accounts become overly dominant, there are fewer opportunities for learning. Still, the students' drawings in Case 2 served as a focus for the discussion and would make a good starting point for a more authoritative phase. In Case 3, we also maintain that the third space was opened up despite the teacher's absence. This is due to the authority of the representation that the students attempted to interpret. However, more research is needed to investigate how teaching should be designed to create a good balance between student-centred and specialised ways of producing and interpreting representations that allows students to work with representations in a personally meaningful way.

An important role that representations play in the teaching and learning of science is that they help students focus on what is significant. Therefore, foregrounding is an important aspect of representations. In Case 1, different aspects of the greenhouse effect were significant. By using the affordance of drawings, the students foregrounded and framed different aspects, and a negotiation between student understanding and scientific explanations was made possible. In Case 3, the students did not have to draw their own representations, but they needed to make meaning by interpreting existing representations in order to use them for a particular purpose (arguing for a standpoint in an SSI). Thus, the affordances of the cluster of modes that make up the representations were connected to argumentation in a public discourse. This is perhaps one of the most important differences between the function of representations in teaching designs focused on the learning of science content and teaching designs focusing on SSI. In an SSI context, the scientific content may, depending on the argument, recede into the background, whereas the representation of, for example, economic factors may be foregrounded, as in Case 3. 
In this article, we have discussed how theoretical and analytical frameworks can enable us to investigate new aspects of using representations in the teaching and learning of science. As an agenda for further research and development, we aim to transform our research findings into teaching recommendations, which will have implications for teachers as well as teacher education.

\section{Acknowledgements}

This work was supported by The Research Council of Norway, grant 249872 .

We also thank the following colleagues in REDE for discussions and comments that have benefited this article: Line Ingulfsen, Mai Lill Suhr Lunde, Mari Sjøberg and Torunn Aanesland Strømme.

We dedicate this article to the memory of REDE member Susannah Solli, who passed away this year.

\section{About the authors}

Erik Knain is professor in science education at the Department of Teacher Education and School Research (ILS) at the University of Oslo, where he is Research leader. His research interests include inquiry-based learning, multimodal language in, education for sustainable development, and socioscientific issues. He is leader of the project Representation and participation in school science (REDE).

Institutional affiliation: Department of teacher education and school research, University of Oslo, P.O. box 1099 Blindern, 0317 Oslo

E-mail: erik.knain@ils.uio.no

Tobias Fredlund is postdoctoral fellow in the REDE project at the Department of Teacher Education and School Research at the University of Oslo. His research interests include the teaching and learning of science, and include topics such as representations, interactive engagement and the variation theory of learning. Institutional affiliation: Department of teacher education and school research, University of Oslo, P.O. box 1099 Blindern, 0317 Oslo

E-mail: tobias.fredlund@ils.uio.no

Anniken Furberg is an associated professor at Department of Teacher Education and School Research, University of Oslo. Furberg's main research interests relate to teaching and learning in technology-rich environments, learning with representations and digital resources in science education and teachers' development of professional digital competences. 
Institutional affiliation: Department of teacher education and school research, University of Oslo, P.O. box 1099 Blindern, 0317 Oslo

E-mail: anniken.furberg@ils.uio.no

Ketil Mathiassen is a senior lecturer at the Department of Teacher Education and School Research, University of Oslo. He has extensive experience in teaching in science in school and teacher education. Mathiassen is cand. real from University of Oslo. Presently Mathiassen is a member of the Expert Group for Digital Assessment at the Norwegian Agency for Digital Learning in Higher Education.

Institutional affiliation: Department of teacher education and school research, University of Oslo, P.O. box 1099 Blindern, 0317 Oslo

E-mail: ketilma@uio.no

Kari Beate Remmen is Associate Professor at the Department of teacher education and school research, University of Oslo. She has experience from several research - and development projects focusing on teaching and learning science outdoors in secondary schools, aiming to make science education more relevant and interesting to students.

Institutional affiliation: Department of teacher education and school research, University of Oslo, P.O. box 1099 Blindern, 0317 Oslo

E-mail: k.b.remmen@ils.uio.no

Marianne Ødegaard is a professor in science education at the Department of Teacher Education and School Research at the University of Oslo. Her research interests are scientific literacy, inquiry-based science, drama in science and video studies in science classrooms.

Institutional affiliation: Department of teacher education and school research, University of Oslo, P.O. box 1099 Blindern, 0317 Oslo

E-mailt: marianne.odegaard@ils.uio.no

\section{References}

Ainsworth, S. (1999). The functions of multiple representations. Computers \& Education, 33, 131-152.

Baldry, A., \& Thibault, P. J. (2006). Multimodal transcription and text analysis. London: Equinox Publishing.

Barab, S., \& Squire, K. (2004). Design-based research: Putting a stake in the ground. Journal of the Learning Sciences, 13(1), 1-14. doi:10.1207/s15327809jls1301_1

Bezemer, J., \& Kress, G. (2015). Multimodality, learning and communication. A social semiotic frame. London: Routledge. 
Fredlund, T., Airey, J., \& Linder, C. (2012). Exploring the role of physics representations: An illustrative example from students sharing knowledge about refraction. European Journal of Physics, 33(3), 657-666. doi:10.1088/0143-0807/33/3/657

Furberg, A., Kluge, A., \& Ludvigsen, S. (2013). Student sensemaking with science diagrams in a computer-based setting. International Journal of Computer-Supported Collaborative Learning, 8(1), 41-64. doi:10.1007/s11412-013-9165-4

Geertz, C. (1973). The interpretation of cultures. New York: Basic Books.

Hansen, P. J. K. (2010). Knowledge about the greenhouse effect and the effects of the ozone layer among Norwegian pupils finishing compulsory education in 1989, 1993, and 2005 What now? International Journal of Science Education, 32(3), 397-419.

Jenkins, E. W. (1994). Pulic understanding of science and science education for action. Journal of Curriculum Studies, 26, 601-611.

Jordan, B., \& Henderson, A. (1995). Interaction analysis: Foundations and practice. The Journal of the Learning Sciences, 4(1), 39-103.

Klosterman, M., Sadler, T., \& Brown, J. (2012). Science teachers' use of mass media to address socio-scientific and sustainability issues. Research in Science Education, 42(1), 51-74. doi:10.1007/s11165-011-9256-z

Knain, E. (2006). Achieving science literacy through transformation of multimodal textual resources. Science Education, 90, 656-659.

Knain, E. (2015). Scientific literacy for participation. A systemic functional approach to analysis of school science discourses. Rotherdam: Sense Publishers.

Knain, E., \& Flyum, K. H. (2003). Genre as a resource for science education: The history of the development of the experimental report. In K. Fløttum \& F. Rastier (Eds.), Academic discourse. Multidisciplinary approaches (pp. 181-205). Oslo: Novus Press.

Kolstø, S. D. (2001). Scientific literacy for citizenship: Tools for dealing with the science dimension of controversial socioscientific issues. Science Education, 85, 291-310.

Krange, I., \& Ludvigsen, S. (2009). The historical and situated nature design experiments Implications for data analysis. Journal of Computer Assisted Learning, 25(3), 268-279. doi:10.1111/j.1365-2729.2008.00307.x

Kress, G. (2010). Multimodality: A social semiotic approach to contemporary communication. London: Routledge.

Kress, G. (2013). What is mode? In C. Jewitt (Ed.), The Routledge handbook of multimodal analysis (pp. 60-75). London: Routledge.

Kress, G., Jewitt, C., Ogborn, J., \& Tsatsarelis, C. (2001). Multimodal teaching and learning: The rhetorics of the science classroom. London and New York: Continuum.

Kress, G., Ogborn, J., Martins, I., \& McGillicuddy, K. (1996). Explaining science in the classroom. Buckingham: Open University Press.

Kress, G., \& Selander, S. (2012). Multimodal design, learning and cultures of recognition. The internet and higher education, 15(4), 265-268.

Lemke, J. L. (1990). Talking science. Norwood, New Jersey: Ablex Publishing.

Lemke, J. L. (1998). Teaching all the languages of science: Words, symbols, images and actions. Retrieved from http://academic.brooklyn.cuny.edu/education/jlemke/papers/barcelon.htm

Ludvigsen, S., Rasmussen, I., Krange, I., Moen, A., \& Middleton, D. (2011). Intersecting trajectories of participation. In S. Ludvigsen, A. Lund, I. Rasmussen, \& R. Säljö (Eds.), Learning across sites: New tools, infrastructures and practices (pp. 105-121). New York: Routledge.

Mercer, N. (2004). Sociocultural discourse analysis: Analysing classroom talk as social mode of thinking. Journal of Applied Linguistics, 1(2), 137-168. 
Mestad, I., \& Kolstø, S. D. (2014). Using the concept of ZPD to explore the challenges of and opportunities in designing discourse activities based on practical work. Science Education, 98(6), 1054-1076.

Moje, E. B., Ciechanowski, K. M., Kramer, K., \& Collazo, T. C. (2004). Working toward third space in content area literacy: An examination of everyday funds of knowledge and Discourse. Reading Research Quarterly, 39(1), 38-70.

Niebert, K., \& Gropengießer, H. (2013). Understanding the greenhouse effect by embodiment - Analysing and using students' and scientists’ conceptual resources. International Journal of Science Education, 36(2), 277-303. doi:10.1080/09500693.2013.763298

Norris, S. P., \& Phillips, L. M. (2003). How literacy in its fundamental sense is central to scientific literacy. Science Education, 87(2), 224-240.

Roberts, D. A. (2007). Scientific literacy/science literacy. In S. K. Abell \& N. G. Lederman (Eds.), Handbook of research on science education (pp. 729-780). London: Lawrence Erlbaum Associates.

Roberts, D. A. (2011). Competing visions of scientific literacy. The influence of a science curriculum policy image. In C. Linder, L. Östman, D. A. Roberts, P.-O. Wickman, G. Erickson, \& A. MacKinnon (Eds.), Exploring the landscape of scientific literacy (pp. 1127). New York: Routledge.

Roth, W.-M., \& McGinn, M. K. (1998). Inscriptions: Toward a theory of representing as social practice. Review of Educational Research, 68(1), 35-59.

Sadler, T. D. (2011). Socio-scientific issues-based education: What we know about science education in the context of SSI. In T. D. Sadler (Ed.), Socio-scientific issues in the classroom: Teaching, learning and research (pp. 355-369). London, New York: Springer.

Scott, P. H., Mortimer, E. F., \& Aguiar, O. G. (2006). The tension between authoritative and dialogic discourse: A fundamental characteristic of meaning making interactions in high school science lessons. Science Education, 90, 605-631.

Sørvik, G. O., \& Mork, S. M. (2015). Scientific literacy as a social practice: Implications for reading and writing in the science classroom. Nordic Studies in Science Education, 11(3), 268-280.

Strømme, T. A., \& Furberg, A. (2015). Exploring teacher intervention in the intersection of digital resources, peer collaboration, and instructional design. Science Education, 99(5), 837-862.

Tang, K. S., Delgado, C., \& Birr Moje, E. (2014). An integrative framework for the analysis of multiple and multimodal representations for meaning-making in science education. Science Education, 98(2), 305-326.

Tasquier, G., Levrini, O., \& Dillon, J. (2016). Exploring students’ epistemological knowledge of models and modelling in science: Results from a teaching/learning experience on climate change. International Journal of Science Education, 38(4), 539-563. doi:10.1080/09500693.2016.1148828

Tippett, C. D. (2016). What recent research on diagrams suggests about learning with rather than learning from visual representations in science. International Journal of Science Education, 38(5), 725-746. doi:10.1080/09500693.2016.1158435

Tytler, R., Prain, V., Hubber, P., \& Waldrip, B. (Eds.). (2013). Constructing representations to learn in science. Rotterdam: Sense Publishers.

Utdanningsdirektoratet (n.d.). Natural science subject curriculum (NAT1-03). Retrieved from https://www.udir.no/kl06/NAT1-03?lplang=eng

Wallace, C. S. (2004). Framing new research in science literacy and language use:

Authenticity, multiple discourses, and the “Third Space”. Science Education, 88(6), 901914. 